\title{
NOTES ON THE LIST OF BRITISH PHYCOMYCETES.
}

\author{
By J. Ramsbottom.
}

In preparing the list of British Phycomycetes in the present number of the Transactions several records have been encountered which cannot be regarded as satisfactory. Notes upon these fungi have therefore been gathered here, together with notes on the nomenclature of certain species.

Reesia amoeboides Fisch; Massee Phycomycetes, p. I 57.

This species, which was recorded "with a certain amount of doubt," is now usually regarded as being the same as Olpidium Lemnae Schroet. The genus Reesia was considered by Fisch to differ from Olpidium in the fact that its zoospores copulate in pairs on leaving the zoosporangium. This point has not been confirmed, and the genus is sunk by most authors though retained by Schroeter in the Pflanzenfamilien.

RHIzidium. This genus was founded by A. Braun (Monatsb. Berl. Acad., p. 59I (I 856) for the species R. mycophilum. Fischer in Rabenh. Krypt. Fl. I. iv., p. I2 I (I892) took this species out of the genus and proposed a new genus $R$ hizophlyctis to include it and other species of Rhizidium which develop outside the matrix of the host. Schroeter (Eng. \& Prantl, Pflanzenfam. I. I, p. 78 (1892)) points this out and uses the name Phlyctochytrium as the equivalent of Fischer's genus Rhizidium and $R$ hizidium Braun for the single species $R$. mycophilum A. Br. Rhizidium Westii (Massee tom. cit., p. 155) becomes therefore Phlyctochytrium Westii (Massee) Lemmermann (Abhandl. Naturw. Ver. Bremen., p. 294 (I903)). The other species of $R$ hizidium given in Massee, $R$. intestinum Schenk, is now considered as two distinct species, Diplophlyctis intestina Schroet. and Phlyctochytrium Schenkii (Dang.) Schroet. As the English record is "on species of Chara and Nitella" it is listed as Diplophlyctis intestina.

ENTOPHLYCTIS HELIOFORMIS (Dang.) nov. comb. This species was described by Dangeard in Bull. Soc. Bot. Fr. XXXIII., p. 356 (I886) and given the name Chytridium helioformis, under which name it appears in Massee tom. cit., p. I58. In 
Journ. de Bot. ii., p. 143 (1888). Dangeard re-describes and figures the species, but changes the name to $C$. heliomorphum, Fischer in Rabenh. Krypt. Fl. I. iv., p. II 8 (1892) placing the species in his new genus Entophlyctis, adopts the later specific name. The earlier specific name must be used no matter what the genus in which the fungus is placed.

Physoderma Comari (Berk. et White) Lagerh. This species was described by Berkeley and White (Ann. Mag. Nat. Hist. Ser. 5, I., p. 27 (1878)) under the name Protomyces Comari. It has usually been included in Protomyces Menyanthis though "the pustules are far more prominent." De Toni and Massee in Journ. Mycol. IV., p. 18 (1888) have a description of "Doassansia Comari (Berk. et Br.), De Ton. et Massee in Herb. Kewensi; Protomyces Comari Berk. et Broome in Ann. Nat. Hist., No. 1708." The number and the locality ("pr. Forfar Britanniae") show that this is supposed to be Berkeley and White's species. The spores are described "sporis late ellipticis, Io $\times 7 \mu$, levibus," whereas the original description says "spores 'OOr-OOI2 inch long, broadly obovate." The type specimen in the Kew herbarium shows spores even exceeding the latter measurement. There does not appear to be anything resembling a Doassansia on the Comarum from Loch of Kinordy, Forfarshire, collected by M. Anderson. (Doassansia Comari De Toni \& Mass. is also given in Massee's Mildews, Rusts and Smuts, 1913, p. 201.) Lagerheim (Bih. K. Svensk. Vet. Akad. Handb. XXIV., iii. 4, p. I I (1898)) places P. Comari Berk. et White in the genus Physoderma. He describes the spores as round or ellipsoid, $25-40 \mu$, with smooth, rather thin membrane and colourless oily contents. Some of the spores in the type specimen reach up to $50 \mu$.

Pythium hydnosporum (Mont.) Schroet. This species is usually written as Pythium Artotrogus de Bary. The conidial form of the fungus is not at present known, but in spite of that it is customary to place it in the genus Pythium. Montagne (Gard. Chron. 1845, p. 640) gave the name Artotrogus hydnosporus to the oosporic stage of the fungus, and this specific name must be retained. The question whether Artotrogus being the name of the perfect stage of the fungus should replace some well established name such as Pythium, is one that can well be left until something more is known of the life history of the fungus in question. Fortunately the principle of Nomina conservanda has been accepted by the International Botanical Congresses.*

* The list of fungus generic names to be conserved was to have been considered at the I.ondon Congress, 1915. 
Pythium pythioides (Roze et Cornu) nov. comb. Roze and Cornu (Ann. Sci. Nat. 5 ser. XI., p. 84 (1869)) described a new genus and species, Cystosiphon pythioides. The genus $C_{\text {ystosiphon they regarded as intermediate between }}$ the Saprolegniineae and Peronosporineae, but apparently considered that the fungus could not be a species of Pythium, because it was parasitic on a phanerogam! Lindstedt (Syn. Saprolegniaceae 1872 , p. 50) placed the fungus in the genus Pythium and gave it the name P. Cystosiphon. As the earliest specific name must be adopted, the fungus must be called Pythium pythioides: unfortunately there is no nomenclatural rule against such illogical combinations.

$P$. incertum Renny. This does not seem to have been described by Renny, though W. G. Smith gives an unsatisfactory figure of it in Gard. Chron. VI., p. I I (1876).

A planes androgynus (Arch.) Humphrey, Saprol. of U.S., p. 134 (1893).

Saprolegnia androgyna Archer in Quart. Journ. Micros. Soc. VII., p. I 23 (1867).

? Aplanes Braunii Reinsch in Jahr. Wiss. Bot. XI., p. 284 (1877).

A. Braunii de Bary in Bot. Zeit. XLVI., p. 650 (1888).

Saprolegnia mucophaga W. G. Sm. in Gard. Chron. XX., p. 78I (I883). The description and the figure are both unsatisfactory. Humphrey Tom. cit., p. I 12, suggests that this and the next species may belong to the genus Pythium.

S. philomukes W. G. Sm. in Diseases of Field and Garden Crops, I884, p. 67. (See also Gard. Chron. XXII., p. 245 $(1884)$.) The descriptions and figures given of this fungus are not such as would enable it to be identified if again met with.

S. corcagiensis Hartog, Quart. Journ. Microscop. Sci. XXVII., p. 429 (1887) is probably A podya lactea. Following Fischer (Rabenh. Krypt. Fl. Pilze I., 4 (I892), pp. 370, 372) the name A podya Cornu has been adopted instead of the more usual Lepromitus Agardh. As Fischer points out, Agardh used the name for a whole host of different organisms from which L. lacteus was taken out by Pringsheim and others as being a species of Saprolegnia. Cornu made it the type of his genus A podya (Ann. Sci. Nat. 5 ser. XV., p. I4 (1872)). The other species that could be identified had already been removed to Saprolegnia by Kützing in 1843 . The fact that this species was the only clearly defined one left of the old genus Leptomitus cannot decide against the adoption of Cornu's generic name.

Ostracoblabe implexa Born. et Flah. was recorded as British 
from specimens found at Clare Island (see Trans. Brit. Mycol. Soc. IV., p. I65 (1913)). Bornet and Flahault in their original investigations regarded it as a member of the Saprolegniaceae (Bull. Soc. Bot. Fr. XXXVI., p. CL. (1889)), but later Bornet (Journ. de Bot. V., p. 397 (I89I)) made further investigations upon it and decided that the filaments described are really the hyphae of the lichen Verrucaria consequens Nyl., which are capable of living in an independent condition as well as in association with the algae, Mastigocoleus testarum and Hyella caespitosa. "L'exposition à l'air libre pendant un temps assez long paraît être la condition nécessaire à la formation du thalle complet. Quand les coquilles se trouvent à une trop grande profondeur, le Lichen parfait ne se developpe pas."

Cystopus. The present writer has shown (Journ. Bot. LIV., p. 76 (I9I6)) that the generic name Cystopus is to be used in preference to the name Albugo, as the latter is pre-Friesian, and Cystopus is also the name applied by de Bary to the oosporic stage. The names given by de Bary should be regarded as the starting point for the nomenclature of the species.

The species described by de Bary as Cystopus spinulosus is regarded by most authors as being the same as $C$. cubicus (Strauss) de Bary ( $C$. Tragopogonis Schroet.). De Bary himself, when describing the species (Ann. Sci. Nat. 4 ser. XX., p. I33 (1863)) was not very certain as to the specific difference, and stated that only culture experiments could decide. The fungus is found on Carduus spp. and does not show the same variation in the oosporic membrane as does the typical $C$. cubicus. In the list it is given the rank of a forma:-Cystopus cubicus (Strauss) de Bary f. spinulosus (de Bary).

ENDODROMIA. This genus was proposed by Berkeley in Hook. Journ. III., p. 79 (I84I). "Peridium very delicate, bursting when immersed in water, and soon breaking up into little granular portions, filled with globose colourless sporidia and radiating branched threads of extreme delicacy. Within each sporidium is a single globose nucleus which moves about within its cells with the greatest activity, from which circumstance I have framed the generic name. .... The genus is evidently a higher development of Mucor, and seems to be an anticipation of Stemonitis." There is no specimen in Berkeley's herbarium at Kew, so one has only the description and an unsatisfactory drawing to go upon. Miss Lister (Mycetozoa, I9II, p. I70) states that it appears possible that it is the same species as Heimerlia hyalina v. Höhn (Ann. Myc. I., p. 39I (1903)) which some have classed with the Mycetozoa, but which does not appear to belong to the group. There can 
be no real certainty about Berkeley's genus, and it would probably be the best policy to totally disregard it.

Mucor mucedo L. var. caninus Mass. (Mass. l.c., p. 87) and $M$. stercoreus Link (p. 88) are both included under $M$. mucedo in the list.

M. subtilissimus Berk. (Hort. Journ. III., p. 98 (I848)) and $M$. tenerrimus Berk. (Hook. Journ. Bot. III., p. 78 (I 84 I)) are not apparently represented in Berkeley's herbarium, and cannot possibly be identified from the drawings and descriptions. The drawing of the latter (Hydrophora tenerrima l.c., t. I, f. B) does not appear to represent a fungus.

$M$. amethysteus Berk. (Eng. F1. V., p. 332 (I 836$)$ ) is not represented in Berkeley's herbarium. The description is insufficient for purposes of re-identification. There is a specimen in Broome's herbarium at the British Museum which is in a very poor condition but may be Rhizopus stolonifer.

$M$. hyalinus Cooke Handb. II., p. 632 (187I). An examination of various specimens on leaves of Buxus, named by Cooke, has not disclosed any member of the Phycomycetes. It has been considered advisable, therefore, to follow the example of most writers and disregard the species.

M. pruinosus B. et Br. (Ann. Mag. Nat. Hist. 4 ser. XV., p. 40, No. I 495 (1875)). The specimens in Berkeley's herbarium and in Broome's herbarium are on broken up soil. It is impossible to find the fungus. The description of the species is too meagre for any identification.

$M$. Lateritius Cooke et Massee in Grev. XVII., p. 3 (I888). Concerning this species Massee says (p. 88): "The present species is not a good Mucor, neither does it agree in all points with any described genus, but until something is known of the sexual stage it is not advisable to remove it from the genus under which it was originally described. Some features suggest an affinity with Sporodinia." $\dagger$

Mucor plumbeus Bonord in Abt. naturf. Ges. Halle VII., p. 109 ( 1864$)$.

M. spinosus van Tiegh.* in Ann. Sci. Nat. 6 ser. IV., p. $390(1876)$.

Mucor repens (Bain.) Sacc. et Trott. in Sacc. Syll. Fung. XXI., p. 82 I (1912).

Glomerula repens Bainier in Bull. Soc. Mycol. Fr. XIX., p. 154 (Igo3).

Mucor Glomerula Lendner, Mucorin. Suisse, p. 69 (1908).

$+M$. lateritius Link Sp. Plant. VI. 1, p. $84(1824)$ is probably Eurotium herbariorum Link.

*M. spinosus Schrank in Denksch. Münchener $\Lambda$ kad. Wissensch., p. 14 (1813) is a species of Achlya. 
SyZYGITES. The present writer has shown (Journ. Bot. LIII., p. 303 (1915)) that as Syzygites megalocarpus Ehrenb. was the name given to the perfect stage (zygospore) of the fungus recently more usually called Sporodinia grandis Link, it should be adopted. Both names were used by Fries in his Systema, as he was unaware of the connection between the sexual and asexual stages.

Rhizopus stolonifer Lind. This species was first described under the name Mucor stolonifer by Ehrenberg (Sylvae myc. Berol. p. 25 (1818)). Ehrenberg in Nova Act. Acad. Leop. $X, p .198$ (1820) gives a long description of the fungus (with a coloured plate) under the name Rhizopus nigricans-" Rhizopus noster a Mucoribus genere differt ob opertas radices (novam partem) et fructus fasciculatos." Fries in Systema III., p. 321 (1832) adopts the name Mucor stolonifer. De Bary first described the zygospores (Beit. Morph. n. Physiol. der Pilze II., p. 25 (1866) ) and used the same name. The specific name "stolonifer" must therefore be used, according to the Rules, and we get thus a name-Rhizopus stolonifer -which is a combination made up of Ehrenberg's two names for the fungus!

PROTOMYCOPSIS PURPUREO-TINGENS nOv. comb.

The species described by Massee (p. 164) as Protomyces purpureo-tingens has been placed in the genus Protomycopsis in the list. The chlamydospores have a warted exospore, and from the figure given (pl. 5, f. 73) they are apparently terminal, as the description--" often with a short persistent portion of the mycelium"-would seem to infer. I have not been able to examine a specimen.

Of the other species of Protomyces given in Massee's book, Protomyces Menyanthis de Bary is listed as Physoderma Menyanthis de Bary; Protomyces Ari Cooke is Melanotaenium Ari (Cke.) Lagerh. 